\title{
Evaluasi Penerapan Sistem Mutu Safe Quality Food: Lesson Learned di Industri Pangan PT XYZ
}

\section{Evaluation of Safe Quality Food System Implementation: Lesson learned from XYZ Food Industry}

\begin{abstract}
Siti Nurjanah ${ }^{1,2) *}$ dan Muhammad Fahrizal Setiawan ${ }^{1)}$
${ }^{1)}$ Departemen Ilmu dan Teknologi Pangan, Fakultas Teknologi Pertanian, Institut Pertanian Bogor, Bogor ${ }^{2)}$ South East Asian Food and Agricultural Science and Technology Center, Institut Pertanian Bogor, Bogor

Abstract. Safe Quality Food (SQF) is food safety and quality management system that apllied food safety principles (US National Advisory Committee on Microbiological Criteria for Food) combined with HACCP system (Codex). SQF standards contains of Module 2 and another modules that suitable for specific porpuses industry. The objectives of this research were to calculate the fulfillment 9 clauses of $S Q F$ Module 2 requirements and its corrective actions to increase the effectiveness of SQF implementation. PT XYZ has been certified SQF management system level 3 for Module 2 and evaluated implementation of this system regularly. This research was conducted in steps: assessment of implementation SQF 7.2 (Module 2), analysis of gap using GAP Analysis Tool, and evaluation of corrective actions for continuous improvement process. Quantitative data showed that PT XYZ complied $100 \%$ for 6 out of 9 clauses of SQF 7.2 Module, and 3 others clauses have implemented 93\% (clause of document control and record), 99\% (clause of attaining food safety and quality), and 94\% (clause of training). Corrective action have decided and implemented effectively. Corrective action were making distribution document's SOP, matrix of hazard significance determination refers to Codex, implementing pre and post-test for evaluating staff's competencies, and integrated audit system between SQF and ISO 9001:2015 using iAuditor application.
\end{abstract}

Keywords: corrective action, food safety, gap analysis, quality management system, safe quality food $(S Q F)$

\begin{abstract}
Abstrak. Safe Quality Food (SQF) merupakan sistem manajemen keamanan pangan yang menerapkan prinsip-prinsip keamanan pangan dari National Advisory Committee on Microbiological Criteria for Food Amerika dan prinsip serta pedoman HACCP dari Codex. Standar SQF terbagi pada beberapa Modul yang sesuai tujuan industri, diantaranya Modul 2 tentang elemen sistem manajemen mutu. Penelitian ini bertujuan untuk mengukur pemenuhan implementasi 9 klausul pada Modul 2 SQF dan melakukan perbaikan untuk meningkatkan implementasi SQF di PT XYZ. PT XYZ telah tersertifikasi SQF Modul 2 dan melakukan evaluasi penerapan sistem tersebut secara berkala. Pengukuran pemenuhan klausul dilakukan dengan analisis kesenjangan menggunakan GAP Analysis Tool dengan skoring penilaian. PT XYZ telah menerapkan 100\% persyaratan pada 6 dari 9 klausul, sedangkan untuk 3 klausul lainnya telah menerapkan 93\% (kausul document control and record), 99\% (klausul attaining food safety and food quality), dan 94\% (klausul training). Tindakan perbaikan untuk pemenuhan dan peningkatan efektivitas penerapan sistem SQF di perusahaan telah dilakukan dan dinilai efektif. Tindakan perbaikan tersebut adalah pembuatan SOP distribusi dokumen, pembuatan matriks penentuan signifikansi bahaya yang mengacu aturan Codex, pelaksanaan pre-test dan post-test singkat sebagai tolak ukur tindakan evaluasi hasil pelatihan, dan penggunaan sistem audit online terintegrasi SQF dengan ISO 9001:2015 menggunakan aplikasi iAuditor.
\end{abstract}

Kata Kunci: analisis kesenjangan, skoring, sistem manajemen mutu, Safe Quality Food, tindakan perbaikan

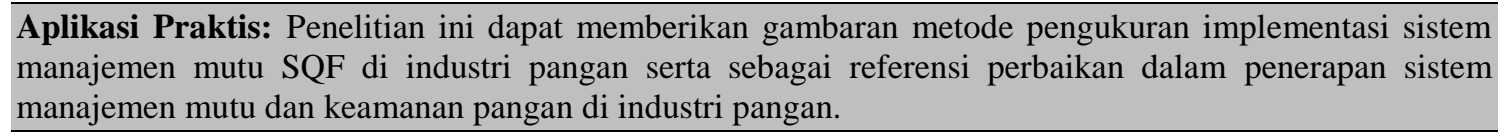

\section{PENDAHULUAN}

PT XYZ merupakan perusahaan populer di Indonesia yang memproduksi makanan ringan dan kukis

Korespondensi: siti.nrjh@gmail.com sebagai produk utamanya. PT XYZ berhasil menjual produknya hingga ke seluruh wilayah Indonesia dan berbagai negara di dunia. Sebagai upaya dalam mempertahankan dan meningkatkan trend positif, diperlukan penyesuaian terhadap kebutuhan konsumen yang dinamis. Penerapan sistem jaminan mutu dan keamanan 
pangan di industri pangan sangat penting untuk memenuhi persyaratan yang diinginkan konsumen. Mutu dianggap sebagai derajat penerimaan konsumen. Mutu sebagai Fitness for Use (cocok atau layak digunakan), berarti suatu produk atau jasa harus dapat memenuhi kebutuhan dan keinginan konsumen (Muhandri dan Darwin 2012).

Berbagai standar nasional maupun internasional terkait mutu dan keamanan pangan terus diperbaharui mengikuti perkembangan ilmu dan teknologi pangan serta isu terkait keamanan pangan yang ada di dunia. Terdapat empat sistem yang diakui oleh Global Food Safety Initiative (GSFI), yaitu British Retail Concortium (BRC), Food Safety System Certification (FSSC), International Food Standard (IFS), dan Safe Quality Food (SQF) (GSFI 2013). Salah satu bentuk komitmen dalam menjamin mutu dan keamanan pangan, PT XYZ telah mengimplementasikan dan melakukan sertifikasi beberapa sistem mutu dan keamanan pangan. Sistem itu antara lain adalah Hazard Analysis and Critical Control Points (HACCP), Sistem Jaminan Halal, ISO 9001:2008 yang akan diperbarui menjadi ISO 9001:2015 dan SQF level 3.

SQF merupakan suatu sistem yang menerapkan prinsip-prinsip keamanan pangan dari National Advisory Committee on Microbiological Criteria for Food (NACMCF) Amerika dan prinsip serta pedoman HACCP yang dibuat oleh Codex Alimentarius Commission (CAC) (SQFI 2013). Standar SQF menggabungkan penerapan keamanan pangan dan manajemen mutu pada semua rantai proses yang terlibat dalam produksi dan pengolahan pangan (Mensah dan Densye 2011). Penerapan sistem SQF dapat memberikan efek positif berupa peningkatan kuantitas ekspor produk berbasis agri-food di Amerika (Seok et al. 2016). Penggunaan sistem SQF juga merupakan pendekatan yang paling praktis dan mudah dalam menerapkan HACCP, serta lebih cepat diterima dengan baik di Australia maupun negara-negara lain (Ropkins dan Beck 2000). Pengembangan sistem SQF sendiri dilakukan di Australia tetapi dimiliki oleh Food Marketing Institut (FMI) di Amerika. Skema sistem SQF ditujukan untuk mempertemukan kebutuhan konsumen dan produsen di seluruh dunia dengan mensyaratkan pemenuhan jaminan sertifikasi manajemen keamanan dan kualitas pangan yang sesuai dengan regulasi lokal dan internasional (DAFWA 2000). Saat ini terdapat dua sistem standar $S Q F$ Codes, yaitu SQF 1000 untuk produsen pertanian dan SQF 2000 untuk industri manufaktur dan distributor (Kobylanski et al. 2011). Sertifikasi sistem SQF terdiri dari 3 level. Level 1 meliputi persyaratan fundamental bagi keamanan pangan, yang berisikan pre-requisite programmes (PRP) dasar untuk keamanan pangan. Level 2 mensyaratkan sertifikasi rencana HACCP, meliputi PRP pada level 1 ditambah dengan pengendalian CCP (Critical Control Point) pada rencana HACCP. Level 3 meliputi persyaratan lengkap sistem manajemen keamanan pangan dan mutu pangan. Pada level 3 disyaratkan pemenuhan persyaratan level 1 dan 2 serta pemenuhan aspek mutu pangan dan pengendalian terkait untuk menghasilkan suatu sistem manajemen keamanan dan mutu pangan yang komprehensif (SQFI 2014a). SQF Codes terdiri dari 6 bagian utama yaitu Komitmen Manajemen, Spesifikasi, Pengendalian Produksi (termasuk persyaratan PRP dan HACCP), Verifikasi, Pengendalian Dokumen dan Records, serta Identifikasi, Penelusuran dan Penarikan Produk (Netterville dan Adendorff 2002).

PT XYZ sendiri telah tersertifikasi SQF level 3. Tanggung jawab pengendalian mutu dan keamanan pangan diberikan kepada Divisi Quality Assurance (QA). Penerapan sistem SQF di perusahaan ini berada pada cakupan manufaktur kategori Bakery and Snack Food Processing. Berdasarkan kategori tersebut, PT XYZ diwajibkan menerapkan $S Q F$ Code Modul 2: System elements dan Modul 11: GMP for processing of food products. Perusahaan menyadari perlunya melakukan evaluasi secara terus menerus terhadap sistem manajemen mutu dan keamanan pangan yang telah diterapkan. SQF yang telah disusun oleh manajemen diperlukan pengawasan dan pemeriksaan terkait pelaksanaannya.

Besarnya volume penjualan produk kukis dengan brand XYZ berimplikasi terhadap penjaminan mutu dan keamanan produk yang dihasilkan dan SQF merupakan sistem yang mengendalikan derajat pencapaian mutu dan keamanan pangan tersebut. Kukis XYZ paling banyak dihasilkan dari lini produksi 6 yang merupakan lini produksi paling mutakhir karena telah diterapkan sistem robotik dalam prosesnya. Adanya gap penerapan sistem SQF pada lini produksi tersebut tentu akan memberikan pengaruh yang besar dalam pemenuhan kualitas produk yang diinginkan. Evaluasi penerapan kondisi aktual SQF di lini produksi 6 dilandasi oleh kesadaran perusahaan dalam melakukan jaminan terhadap sistem manajemen mutu dan keamanan pangan. Tingkat pemenuhan dan kesenjangan yang ada perlu diketahui sehingga dapat dilakukan penyesuaian dan perbaikan dalam mencapai sistem manajemen mutu dan keamanan pangan yang lebih efektif. Namun evaluasi dalam penelitian ini terbatas pada Modul 2 SQF 7.2, sedangkan Modul 11 yang membahas lebih rinci tentang proses tidak dilakukan. Penelitian ini bertujuan untuk mengukur pemenuhan implementasi 9 klausul pada Modul 2 SQF dan melakukan perbaikan untuk meningkatkan implementasi pelaksanaan sistem manajemen SQF pada PT XYZ.

\section{BAHAN DAN METODE}

\section{Metode}

Penelitian dilakukan di PT XYZ bagian Departemen Quality Assurance pada Bulan Februari-Mei tahun 2017. Penelitian dilakukan dalam beberapa tahapan, yaitu 1) Kajian implementasi SQF Modul 2, 2) Analisis kesenjangan (GAP Analysis) dan kuantifikasi, 3) Tindakan perbaikan dan evaluasi efektivitas tindakan 
perbaikan. Bahan acuan yang digunakan dalam penelitian adalah General Guidance SQF 7.2 Modul 2: System Elements, laporan audit internal PT XYZ serta dokumen HACCP PT XYZ.

\section{General guidance SQF 7.2, modul 2: system elements}

General Guidance for Developing, Documenting, Implementing, Maintaining, and Auditing an SQF System, Modul 2: System Elements. Modul 2 berisi 9 klausul, 42 sub-klausul dan 119 sub-sub-klausul tentang sistem elemen SQF. Klausul sendiri merupakan persyaratan yang harus dipenuhi oleh pihak yang akan melakukan sertifikasi. Isi klausul yang terdapat dalam dokumen SQF Modul 2 adalah tentang struktur $S Q F$ System serta jumlah klausul dan sub-klausul (Tabel 1).

Tabel 1. Struktur system elements SQF 7.2

\begin{tabular}{clcc}
\hline Nomor & \multicolumn{1}{c}{ Klausul } & $\begin{array}{c}\text { Jumlah } \\
\text { Sub- } \\
\text { Klausul }\end{array}$ & $\begin{array}{c}\text { Jumlah } \\
\text { Sub-Sub- } \\
\text { Klausul }\end{array}$ \\
\hline 2.1 & $\begin{array}{l}\text { Management commitment } \\
\text { Document control and }\end{array}$ & 6 & 27 \\
2.2 & 2 & 6 \\
& $\begin{array}{l}\text { record } \\
2.3\end{array} \quad \begin{array}{l}\text { Specification and product } \\
\text { development }\end{array}$ & 5 & 19 \\
2.4 & Attaining food safety & 9 & 23 \\
2.5 & SQF system verification & 7 & 15 \\
2.6 & $\begin{array}{l}\text { Product identification, } \\
\text { trace, withdrawal and recall }\end{array}$ & 3 & 8 \\
2.7 & Site security & 1 & 2 \\
2.8 & Identity preserved foods & 2 & 12 \\
2.9 & Training & 7 & 7 \\
& Jumlah & 42 & 119 \\
\hline
\end{tabular}

Sumber: (SQFI 2014b), Modul 2

\section{Kajian implementasi SQF modul 2}

Tahapan ini merupakan evaluasi tingkat penerapan SQF. Data diperoleh dari hasil kajian dokumen sistem yang telah dibuat, observasi lapangan secara periodik, dan peninjauan penerapan SQF secara aktual. Observasi dilakukan melalui pengecekan kinerja aktual, pengecekan record atau laporan harian serta wawancara kepada para pegawai yang terlibat. Observasi dilakukan secara kualitatif dan kuantitatif untuk mengumpulkan informasi dari seluruh bagian yang terlibat sesuai kebutuhan di lapangan yang dibandingkan dengan panduan pertanyaan audit serta persyaratan yang telah ditentukan SQF.

\section{Analisis kesenjangan (GAP analysis)}

Tahapan ini merupakan analisis berdasarkan hasil temuan aktual pada tahapan sebelumnya. GAP Analysis dilakukan untuk mengetahui sejauh mana PT XYZ dalam memenuhi persyaratan SQF dengan membandingkan pemenuhan sistem manajemen mutu dan keamanan pangan di perusahaan dengan persyaratan standar sistem Modul 2 SQF 7.2. Hasil observasi diolah menggunakan checklist skoring (Tabel 2) untuk mengukur tingkat implementasi SQF di perusahaan. Penilaian skoring dibuat berdasarkan perbandingan kondisi aktual dengan isi klausul Modul 2 SQF 7.2. Ketentuan penilaian diadopsi dari ISO 9001:2000 GAP Analysis Tool (Bakhtiar dan Bambang 2009) karena lebih mudah dipahami dan digunakan. Skor penilaian dilakukan untuk setiap sub-sub-klausul dengan jumlah total 119 sub-sub-klausul, kemudian dirata-ratakan dalam satu klausul. Persentase 100\% didapatkan apabila semua sub-sub-klausul memenuhi skor maksimal (nilai $5)$.

Tabel 2. Ketentuan skoring penilaian dan presentase pemenuhan penerapan Modul 2 SQF 7.2

\begin{tabular}{cl}
\multicolumn{3}{c}{ pemenuhan penerapan Modul 2 SQF 7.2 } \\
\cline { 1 - 1 } Skor & \multicolumn{1}{c}{ Skoring Penilaian } \\
\hline 0 & $\begin{array}{l}\text { Jika perusahaan tidak memahami apa yang } \\
\text { dipersyaratkan }\end{array}$ \\
1 & $\begin{array}{l}\text { Jika perusahaan tidak melakukan persyaratan tersebut } \\
\text { Jika perusahaan memahami persyaratan tersebut } \\
\text { tetapi tidak melakukannya. }\end{array}$ \\
3 & $\begin{array}{l}\text { Jika perusahaan melakukan persyaratan terkadang } \\
\text { saja. }\end{array}$ \\
4 & $\begin{array}{l}\text { Jika perusahaan melakukan persyaratan tetapi belum } \\
\text { sempurna }\end{array}$ \\
5 & Jika perusahaan melakukan persyaratan dengan baik \\
\hline $75-$ & Presentase Pemenuhan per Klausul \\
$100 \%$ & $\begin{array}{l}\text { Perusahaan telah memenuhi persyaratan klausul SQF } \\
50-\end{array}$ \\
$74 \%$ & persyaratan SQF \\
$1-49 \%$ & Sistem perusahaan sangat butuh perbaikan karena \\
& berbeda jauh dari persyaratan klausul SQF \\
\hline Sumber: (ISO 2000)
\end{tabular}

\section{Efektivitas tindakan perbaikan}

Tahapan ini berupa penentuan dan pelaksanaan tindakan perbaikan berdasarkan hasil evaluasi pada tahapan sebelumnya. Tindakan perbaikan dapat pula berupa rekomendasi untuk pengembangan sistem manajemen mutu dan keamanan pangan di perusahaan. Tindakan perbaikan dievaluasi efektifitasnya dengan melakukan pengukuran terhadap parameter tertentu pada klausul yang terkait (Audit Internal, distribusi dokumen, implementasi HACCP dan pengukuran hasil pelatihan).

\section{HASIL DAN PEMBAHASAN}

\section{Pemenuhan persyaratan modul 2 SQF 7.2}

PT XYZ berkomitmen memenuhi tuntutan pelanggan dengan mengimplementasikan dan melakukan sertifikasi sistem manajemen mutu dan keamanan pangan. Sistem itu antara lain adalah SQF level 3, HACCP, Sistem Jaminan Halal, ISO 9001. Persyaratan pada standar Modul 2 SQF 7.2 terbagi menjadi 9 klausul seperti yang disajikan dalam Tabel 1, dan setiap klausul terdapat sub-klausul masing-masing. PT XYZ telah menerapkan sistem mutu dan keamanan pangan SQF dan memperoleh sertifikat dari badan sertifikasi independen. Berdasarkan kajian persyaratan Modul 2 SQF 7.2, secara umum menunjukkan bahwa PT XYZ telah menerapkan, mendokumentasikan, memelihara, dan melakukan perbaikan berkelanjutan sistem manajemen mutu dan keamanan pangan SQF sesuai dengan standar yang berlaku seperti yang disajikan dalam Tabel 3.

\section{Klausul 2.1 management commitment}

Klausul Management Commitment memiliki 6 subklausul tentang kebijakan mutu, tanggung jawab 
manajemen, sistem manajemen mutu, dan keamanan pangan, tinjauan manajemen, manajemen komplain, dan perencanaan kelangsungan bisnis.

Tabel 3. Checklist penilaian pemenuhan penerapan klausul modul 2 SQF 7.2

\begin{tabular}{lcc}
\multicolumn{1}{c}{ Klausul } & $\begin{array}{c}\text { Nilai Rataan } \\
\text { dari Sub- } \\
\text { sub-klausul }\end{array}$ & $\begin{array}{c}\text { Rataan Pre- } \\
\text { sentase Peme- } \\
\text { nuhan (\%) }\end{array}$ \\
\hline $\begin{array}{l}\text { 2.1 Management commitment } \\
\text { 2.2 Document control and }\end{array}$ & 5 & 100 \\
record & 4.67 & 93 \\
2.3 Specification and product & 5 & 100 \\
development & & \\
2.4 Attaining food safety and & 4.95 & 99 \\
food quality & & 100 \\
2.5 SQF system verification & 5 & 100 \\
2.6 Product identification, trace, & 5 & 100 \\
withdrawal and recall & 5 & 100 \\
2.7 Site Security & 5 & 94 \\
2.8 Identity preserved foods & 5 & \\
2.9 Training & 4.71 & \\
\hline
\end{tabular}

Keseluruhan persyaratan klausul ini telah dimiliki dan diimplementasikan oleh PT XYZ dengan baik (100\%). Klausul ini merupakan klausul fundamental dalam penerapan SQF 7.2, yang berisi persyaratan menyangkut sistem yang harus dibangun, dipelihara, dan dikendalikan di perusahaan karena mempengaruhi integritas dan keamanan produk. Tidak terpenuhinya implementasi klausul ini dapat menyebabkan tidak dikeluarkannya sertifikat. Berdasarkan SQFI (2014b), klausul ini berkaitan dengan tingkat komitmen dan dukungan manajemen dalam efektifitas implementasi sistem manajemen mutu dan keamanan pangan SQF. Manajemen harus mampu mendorong lingkungan proaktif diantara karyawan terhadap pemenuhan aspek mutu dan keamanan pangan.

Manajemen PT XYZ dalam memenuhi komitmen dan tanggung jawab atas pelaksanaan SQF 7.2 telah melakukan sosialisasi kepada semua karyawan untuk dapat meningkatkan kepedulian mengenai pentingnya produksi pangan aman dan sehat, sesuai dengan Undang-Undang Pangan yang berlaku, dan pemenuhan kebutuhan pelanggan. Kebijakan mutu PT XYZ telah ditetapkan, disosialisasi, dan diletakkan ditempat strategis pabrik sehingga mudah dilihat oleh seluruh karyawan. Kebijakan ini didukung oleh visi perusahaan yaitu No Subtitute for Quality. Dalam hal peningkatkan kinerja dan pencapaian sasaran mutu dan keamanan pangan, manajemen menjamin kecukupan sumber daya yang dibutuhkan serta melakukan pengkajian jalannya sistem. Sebagai tanggung jawab perusahaan dalam pemenuhan kepuasan pelanggan, PT XYZ memiliki prosedur penanganan komplain yang terorganisir. Sesuai yang dipersyaratkan SQF, keseluruhan persyaratan fundamental ini akan dibahas dalam Management Review Meeting yang dilaksanakan setahun sekali.

\section{Klausul 2.3 spesification and product development}

Klausul ini memiliki 5 sub-klausul yaitu pengembangan produk baru, bahan baku dan kemasan, finish product (FG), serta kontrak manufacturing, dan contract service providers. Spesifikasi merupakan standar yang ditetapkan terhadap kualifikasi bahan baku atau bahan kemasan, tahapan proses dan produk akhir. Dokumen spesifikasi harus dikendalikan oleh perusahaan. Dokumen spesifikasi yang digunakan PT XYZ adalah spesifikasi bahan baku dan kemasan, spesifikasi formula spesifikasi proses pada setiap tahapan yang diterjemahkan kedalam Standard Operating Procedure (SOP), Work Instruction (WI), dan spesifikasi produk akhir termasuk juga spesifikasi untuk crumb dan produk Work In Process (WIP). Daftar keseluruhan dokumen spesifikasi dipelihara oleh Document Controller dan masing-masing User serta dilakukan kajian setiap tahun dan atau jika terdapat perubahan. Hal ini telah sesuai dengan isi klausul yang dipersyaratkan.

Terdapat prosedur dalam pengembangan dan penyetujuan spesifikasi bahan baku dan kemasan, keduanya harus sesuai peraturan perundang-undangan yang berlaku seperti SNI, BPOM, dan lainnya. Raw Material (RM) dan Packaging Material (PM) harus divalidasi terlebih dahulu untuk menjamin keamanan dan mutu bahan sesuai dengan kualifikasi yang diinginkan. Dalam melakukan validasi dibutuhkan dokumen dari supplier seperti Certificate of Conformance (CoC), Certificate of Analysis (CoA), atau dilakukan uji sampling. Sedangkan untuk kemasan harus ada sertifikat kontak langsung dengan produk serta potensi migrasi bahan. Sedangkan untuk spesifikasi FG meliputi kriteria batas kandungan mikroba dan batas cemaran kimia, keterangan label kemasan, atribut mutu fisik (warna, tekstur, dan ukuran), atribut mutu kimia (kadar garam, kadar air), atribut mutu mikrobiologi (jumlah kapang dan kamir). Dalam pengembangan produk baru, manajemen PT XYZ khususnya divisi New Product Development yang merupakan bagian dari RND menetapkan metode dalam mendisain dan mengembangkan produk dari konsep menjadi produk komersial. Terdapat lima tahapan yang dilakukan, 1) uji feasibility produk 2) desain produk 3) tahap pengembangan produk, 4) launching produk, dan 5) evaluasi produk. Shelf life trial juga dilakukan untuk mendapatkan tanggal "best before" atau sejenisnya. Proses tersebut diikuti dengan kajian verifikasi food safety and quality plan untuk menjamin aspek keamanan dan mutu produk.

Banyak kewajiban dalam proses produksi atau fasilitas yang mungkin dikerjakan oleh pihak lain yang bukan bagian dari manajemen, tetapi mereka dikontrak untuk melakukan pekerjaan tersebut. Hal inilah yang disebut dengan contract service providers. PT XYZ menggunakan jasa service providers dalam proses penanganan pest, kebersihan, kontraktor, kantin, laundry, keamanan, dan transportasi. Dalam persetujuan kontrak dengan penyedia jasa, PT XYZ memiliki spesifikasi terhadap kesesuaian dengan persyaratan SQF. Sedangkan contract manufactures dapat diartikan sebagai maklon. PT XYZ tidak memiliki maklon dengan perusahaan lain sehingga tidak berkewajiban untuk memenuhi sub-klausul contract manufactures. Implementasi klausul ini telah terpenuhi sesuai persyaratan $(100 \%)$. 


\section{Klausul 2.5 SQF system verification}

Klausul 2.5 ini terdiri dari 7 sub-klausul, yaitu validasi, verifikasi, audit internal, tindakan perbaikan dan pencegahan dan verifikasi terhadap tindakan perbaikan. Proses validasi dan verifikasi perlu dilakukan dalam pemeliharaan sistem HACCP. Validasi merupakan aktivitas untuk membuktikan bahwa persyaratan telah dikontrol secara efektif, sedangkan verifikasi merupakan proses konfirmasi melalui bukti hasil kajian persyaratan yang telah terpenuhi (GFSI Guidance Document version 6.2) (GFSI 2013). Berdasarkan persyaratan SQF, proses validasi harus diaplikasikan secara ilmiah untuk membuktikan bahwa batas kritis setiap Critical Control Points (CCP) dan Critical Quality Points (CQP) tercapai sesuai dengan hasil yang diinginkan. Selain itu, proses verifikasi diaplikasikan untuk seluruh sistem SQF termasuk juga penggunaan metode sampling, audit, revalidasi untuk menggambarkan sistem SQF berjalan secara efektif.

Tanggung jawab pelaksanaan aktivitas validasi dan verifikasi dipegang oleh SQF Practitioner agar berjalan efektif dan sesuai jadwal. Semua kegiatan verifikasi dan validasi terkait sistem HACCP yang dilakukan PT XYZ terlebih dahulu mendapat persetujuan langsung dari $S Q F$ Practitioner dibawah Departemen Quality Assurance. Hasil dari aktivitas tersebut nantinya akan dibahas dalam Management Review Meeting setiap tahunnya dan digunakan dalam memperbarui sistem manajemen mutu dan keamanan pangan. Jadwal pelaksanaan verifikasi dan validasi untuk setiap proses dapat disesuaikan dengan aktivitas audit yang sedang dilakukan, seperti audit GMP, SQF atau pada saat HACCP review.

Alat ukur produk telah secara aktif dikalibrasi sesuai jadwal kalibrasi baik internal maupun eksternal. Biasanya kalibrasi internal dilakukan setiap bulan, sedangkan eksternal setiap tahun. Selain alat, juga terdapat aktivitas sampling, inspeksi, dan atau analisis dalam pengujian bahan baku, kemasan, produk akhir maupun produk selama proses. Dalam melakukan kalibrasi atau analisa oleh pihak eksternal, perusahaan memilih laboratorium yang telah memperoleh akreditasi ISO 17025 sesuai dengan yang dipersyaratkan SQF.

Klausul ini juga mensyaratkan dilakukannya tindakan koreksi terhadap ketidaksesuaian atau gap berdasarkan asal masalah. Akar masalah terjadinya ketidaksesuaian harus diketahui agar dapat dilakukan tindakan koreksi yang sesuai. Selanjutnya tindakan koreksi akan diverifikasi apakah telah dilaksanakan secara efektif. Masalah paling berat dalam melakukan tindakan koreksi apabila terjadi perubahan yang sporadis dan penyebabnya tidak segera diketahui. Hal ini biasanya terjadi saat mendiagnosa penyebab. Sehingga perusahaan memutuskan untuk bertindak sigap dalam menelusuri akar masalah. Biasanya penelusuran dilakukan bersama dengan departemen yang berkaitan untuk meningkatkan keefektifan hasil.

Standar SQF mensyaratkan perusahaan melakukan audit internal dalam rangka memastikan lingkungan pabrik dan peralatan proses dipelihara pada kondisi yang sesuai untuk produksi pangan. Inspeksi ini meliputi inspeksi pabrik untuk mengidentifikasi resiko ke produk yang berasal dari bangunan atau peralatan (audit GMP). Untuk meningkatkan kinerja sistem manajemen mutu dan keamanan pangan SQF, PT XYZ secara teratur memantau beberapa aspek yang berkaitan dengan pemantauan dan pengukuran yang menyangkut aspek internal, seperti audit internal untuk mengetahui kesesuaian dengan persyaratan atau spesifikasi. Sedangkan audit eksternal merupakan aspek kepuasan pelanggan dan dibahas dalam tinjauan manajemen meeting yang secara rutin dilaksanakan setiap tahun sekali.

Selama proses pemantauan apabila ditemukan suatu ketidaksesuaian maka harus dilakukan tindakan perbaikan, contoh jika ada ketidaksesuaian yang ditemukan dari hasil audit maka kesenjangan tersebut harus segera dilaksanakan dengan mengisi report tindakan koreksi dan harus ditindaklanjuti kepada departemen yang berkaitan. Prosedur audit internal telah didokumentasikan dalam SOP. Tim audit internal dipilih dari beberapa divisi yang kemungkinan berkaitan dengan aktivitas manejemen mutu dan keamanan yang dipersyaratkan SQF. Jadwal untuk penyusunan audit internal didasarkan pada tingkat risiko. Untuk audit internal SQF dilakukan setiap tahun sekali mengikuti persiapan audit eksternal pada setiap area yang bersangkutan. Dalam setahun terlalu banyak audit internal yang dilakukan seperti Audit GMP, SQF, RSPO, dan Plant Walk. Aktivitas audit belum ditambah dengan audit dari supplier atau distributor tujuan pasar. Pelaksanaan audit secara keseluruhan sangat baik, tetapi jumlah tim auditor kurang sesuai dengan banyaknya aktivitas audit yang dilakukan. Sistem audit terintegrasi perlu dijalankan untuk mereduksi jumlah audit. Oleh karena itu, sistem audit terintegrasi antara SQF dan ISO 9001:2015 dibuat. Audit ini dikelompokkan berdasarkan divisi di perusahaan. Untuk meningkatkan keefektifan audit, proses audit dapat dijalankan menggunakan aplikasi berbayar iAuditor. Aplikasi tersebut dapat mempercepat proses audit dan memudahkan penulisan report karena tidak lagi berbasis kertas melainkan smartphone. Implementasi klausul ini telah terpenuhi sesuai persyaratan $(100 \%)$.

\section{Klausul 2.6 product identification, trace, withdrawal and recall}

Klausul terdiri dari 3 sub-klausul, tentang identifikasi produk, ketertelusuran produk serta penarikan produk atau recall. Identifikasi produk sangat penting dilakukan karena dapat berakibat fatal apabila terjadi kesalahan dalam produksi atau distribusi. SQF mensyaratkan perusahaan memiliki prosedur atau panduan identifikasi produk untuk setiap proses produksi dan penyimpanan. PT XYZ memiliki format identifikasi yang khas dan berbeda sesuai kebutuhan untuk setiap bahan baku dan kemasan, produk WIP, serta hasil produk akhir. Khusus untuk identifikasi produk akhir dalam kemasan disesuaikan dengan regulasi negara tujuan distribusi. Sistem pelabelan digunakan dalam 
mengidentifikasi produk. Umumnya setiap kode dalam label disertai dengan tanggal penerimaan/produksi untuk memudahkan sistem penelusuran. Selain label, PT XYZ menggunakan komponen warna pada palet dan plastik untuk mengidentifikasi produk terutama pada produk yang mengandung alergen yaitu warna merah.

Daya telusur (Traceability) wajib dimiliki perusahaan sebagai bagian dari sistem SQF. Sistem daya telusur PT XYZ diatur dalam Manual Traceability. Daya telusur di perusahaan dibagi menjadi dua, yaitu $u p$ stream yang berarti penelusuran produk akhir hingga ke tangan distributor dan down stream yang berarti penelusuran produk akhir hingga bahan baku yang digunakan. Daya telusur PT XYZ dijalankan menggunakan sistem yang terintegrasi. Setiap tahun sekali dilakukan uji coba daya telusur sesuai dengan persyaratan SQF. Sistem daya telusur di PT XYZ mencapai angka 100\%, artinya setiap produk yang dihasilkan dapat ditelusur.

Recall produk merupakan cara yang bertujuan menarik kembali satu unit produk yang tidak sesuai dari konsumen atau konsumen akhir, sedangkan withrawal produk adalah cara yang bertujuan menarik kembali satu unit produk dari konsumen tetapi bukan konsumen akhir (FSA 2013). Penarikan produk terjadi apabila ditemukan masalah keamanan produk di pasar atau ketidaksesuaian dengan regulasi dan konsumen disarankan untuk tidak mengonsumsi produk tersebut. Proses withdrawal dan recall di PT XYZ diatur dalam Manual Witrawal and Recall. Penetapan status recall diikuti dengan investigasi akurat dan tindakan koreksi oleh perusahaan. Manajer senior seperti kepala divisi dalam perusahaan ikut terlibat jika proses ini terjadi. Uji coba mock recall dilakukan setiap tahun sekali untuk melihat keefektifan prosedur mengingat proses ini bersifat krusial. Selain kepada badan pemerintahan terkait, perusahaan harus melaporkan ke Certification Body dan SQFI dalam 24 jam jika terjadi recall produk. Implementasi klausul ini telah terpenuhi sesuai persyaratan $(100 \%)$.

\section{Klausul 2.7 site security}

Klausul ini terdiri dari 1 sub-klausul, tentang prosedur atau pemenuhan protokol food defense. Masalah keamanan baik lingkungan pabrik maupun produk menjadi isu mengalami perkembangan nyata dalam standar ini. Sistem keamanan dibangun untuk menjamin pabrik dan produk dilindungi dari serangan pihak luar, pencurian, sabotase/tindakan terorisme, dan kontaminasi yang disengaja dalam lingkungan pabrik. Standar ini mensyaratkan dilakukannya kajian risiko pengaturan keamanan pabrik. Perusahaan telah memiliki protokol tentang kriteria pencegahan kejadian tersebut. Protokol dipersyaratkan harus dapat mengidentifikasi bagaimana perusahaan membatasi akses ke fasilitas pabrik atau bagian tertentu di lini produksi kepada orang-orang yang telah mendapat izin. Keamanan penyimpanan transportasi produk dan peralatan juga termasuk protokol. Aktivitas dalam pemenuhan klausul ini ialah prosedur pemberian akses masuk kepada karyawan, kontraktor, dan tamu perusahaan. Implemen- tasi klausul ini telah terpenuhi sesuai persyaratan $(100 \%)$.

\section{Klausul 2.8 identity preserved foods}

Klausul ini terdiri dari 2 sub-klausul, tentang syarat bahan pengawet pangan dan manajemen alergen. Identity preserved food (IPF) merupakan produk yang memiliki klaim nutrisional, ethical, ataupun keagamaan seperti klaim organik, halal, koshr, Genetically Modified Organism (GMO) free, dan lainnya. Alergen juga termasuk ke dalam klausul ini tetapi dibahas secara terpisah pada sub klausul berbeda. Penanganan IPF diperlukan pemisahan dengan bahan baku atau produk lain di setiap tahapan proses atau penyimpanan. Pemenuhan sistem daya telusur, identifikasi produk antara dan produk akhir hendaknya dibuat untuk memastikan semua klaim yang berhubungan dengan asal usul atau jaminan tertentu telah sesuai. Klaim yang digunakan PT XYZ hanya halal. Semua produk yang dihasilkan berasal dari bahan baku halal, sehingga tidak memerlukan proses pemisahan proses produksi. Pemenuhan klaim halal mengikuti prosedur Sistem Jaminan Halal (SJH) dari MUI. PT XYZ telah mendapatkan sertifikat SJH dengan nilai A, dan telah memenuhi klausul ini.

Alergen dapat menjadi masalah signifikan apabila penanganannya tidak benar. Hal ini karena alergen dapat menyebabkan efek kesehatan skala ringan, berat, hingga kematian. Kebanyakan alergen merupakan protein dan tidak terdenaturasi pada proses produksi. Alergen secara kontinyu telah menjadi penyebab jumlah penarikan produk yang signifikan di Amerika Utara dan Eropa. Mengingat pasar PT XYZ mencakup pasar dunia dan setiap negara mempunyai daftar alergen masing-masing, perusahaan perlu memiliki sistem manajemen alergen untuk mencegah kontaminasi. Manajemen yang dimaksud meliputi pengaturan alergen di perusahaan dari berbagai aspek, mulai dari perencanaan, kajian resiko, hingga produk akhir. Kajian resiko alergen harus mempertimbangkan beberapa hal seperti bentuk fisik produk (bubuk, cair, partikel), titik potensi kontaminasi silang, dan kajian risiko kontaminasi silang setiap proses. PT XYZ memiliki manual terkait Allergen Management dan pelaksanaannya termasuk sistem HACCP perusahaan.

Penanganan alergen di PT XYZ dimulai dari bagian preparasi. Terdapat kode warna khusus sebagai wadah produk mengandung alergen, yaitu warna merah. Ruang persiapan bahan baku dan peralatan khusus alergen terpisah dengan produk non-alergen. Selain warna, terdapat label khusus untuk produk mengandung alergen pada tahapan proses. PT XYZ memiliki prosedur cleaning alergen untuk menghilangkan residu alergen pada fasilitas produksi. Terdapat tiga prosedur cleaning di lini produksi, yaitu cleaning biasa dan cleaning detil untuk pergantian produk non-alergen dan cleaning alergen. Validasi keefektifan cleaning alergen dilakukan setahun sekali. Kebanyakan produk di PT XYZ menggunakan beberapa bahan baku yang mengandung alergen seperti telur, susu, dan kacang. Perusahaan tetap 
harus menyesuaikan daftar alergen negara tujuan ekspor karena bisa jadi berbeda antara negara satu dengan yang lain. Selain itu, dalam kemasan produk akhir disyaratkan untuk mencantumkan keterangan bahwa kemungkinan produk mengandung alergen berdasarkan regulasi. Implementasi klausul ini telah terpenuhi sesuai persyaratan $(100 \%)$.

\section{Analisis kesenjangan, tindakan perbaikan dan efek- tivitasnya}

Presentase pemenuhan implementasi klausul modul 2 SQF 7.2 (Tabel 3). Hasil yang diperoleh menunjukkan bahwa dari kesembilan klausul utama, terdapat tiga klausul yang tidak mendapatkan nilai $100 \%$ atau terdapat gap, diantaranya klausul 2.2 Document Control and Record (pemenuhan 93\%), 2.4 Attaining Food Safety and Food Quality (pemenuhan 99\%), dan 2.9 Training (pemenuhan 94\%). Kesenjangan klausul 2.2 adalah pada pendistribusian dokumen dan penataan dokumen dalam file penyimpanan. Kesenjangan klausul 2.4 tentang attaining food safety and food quality adalah penyusunan tabel HACCP pada produksi packing 6 belum diperbarui beberapa bagian. Kesenjangan pada klausul 2.9 training adalah evaluasi pemahaman karyawan terkait pelatihan yang diberikan baru dilakukan pada sebagian pelatihan.

Serangkaian tindakan perbaikan dilakukan untuk mengatasi kesenjangan tersebut (Tabel 4), untuk mencegah adanya penyimpangan pelaksanaan sistem serta untuk meningkatkan efektifitas proses pengendalian melalui penguatan implementasi sistem di lapangan. Berdasarkan hasil analisis kesenjangan tersebut, tindakan perbaikan yang dilakukan yaitu pembuatan SOP distribusi dokumen, pembuatan matriks penentuan signifikansi bahaya yang mengacu aturan CODEX; pelaksanaan pre-test dan post-test singkat sebagai tolak ukur tindakan evaluasi hasil pelatihan, dan penggunaan sistem audit online terintegrasi SQF dengan ISO 9001:2015 menggunakan aplikasi iAuditor dapat dijadikan upaya dalam peningkatan efektivitas penerapan sistem SQF di perusahaan.

Dampak dari hasil Tindakan Perbaikan dievaluasi berdasarkan perubahan setelah dilakukan tindakan perbaikan dan sebelumnya (Tabel 4). Semua tindakan perbaikan memberikan perubahan yang positif pada setiap klausul dibandingkan dengan sebelumnya. Hasil kajian ini menunjukan PT XYZ telah melaksanakan penerapan SQF 7.2 dengan sangat baik dan terbukti layak mendapatkan sertifikasi mengingat SQF sendiri merupakan poin utama dalam penjaminan dan pengendalian mutu dan keamanan produk yang harus dipahami secara menyeluruh. Perusahaan telah melakukan proses perencanaan, pelaksanaan, evaluasi dan tindakan perbaikan sesuai sistem mutu yang dijalankan.

\section{KESIMPULAN}

Hasil kajian pemenuhan persyaratan Modul 2 sistem manajemen mutu dan keamanan pangan SQF 7.2 di PT $\mathrm{XYZ}$ dengan menggunakan gap analysis tools menunjukkan bahwa sebagian besar persyaratan dalam klausul telah terpenuhi. PT XYZ memperoleh hasil presentase pemenuhan $100 \%$ untuk 6 dari 9 klausul.

Tabel 4. Evaluasi tindakan perbaikan berdasarkan klausul Modul 2 SQF 7.2

\begin{tabular}{|c|c|c|c|}
\hline Klausul & Kondisi Aktual & Tindakan Perbaikan & Perubahan Setelah Perbaikan \\
\hline $\begin{array}{c}\text { Klausul } 2.5 \\
\text { SQF System } \\
\text { Verification }\end{array}$ & $\begin{array}{l}\text { - Implementasi sudah sesuai dengan } \\
\text { klausul yang dipersyaratkan. } \\
\text { - Frekuensi audit. internal dalam satu } \\
\text { tahun terlalu padat. } \\
\text { - Audit dilakukan secara paper- } \\
\text { based. }\end{array}$ & 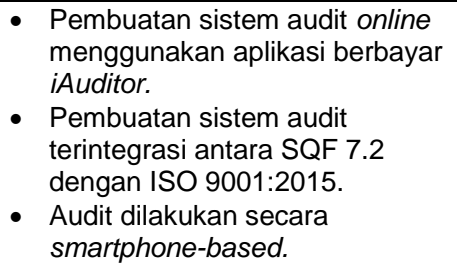 & $\begin{array}{l}\text { - Jumlah audit internal dalam } \\
\text { satu tahun tereduksi. } \\
\text { - Penulisan report lebih } \\
\text { praktis dan mudah. } \\
\text { - Pelaksanaan audit internal } \\
\text { semakin efektif. }\end{array}$ \\
\hline $\begin{array}{c}\text { Klausul } 2.2 \\
\text { Document } \\
\text { Control and } \\
\text { Record }\end{array}$ & $\begin{array}{l}\text { - Terdapat mekanisme distribusi } \\
\text { dokumen tetapi SOP belum } \\
\text { dibakukan. } \\
\text { - Terdapat beberapa dokumen di lini } \\
\text { produksi yang tidak sesuai dengan } \\
\text { daftar isi dokumen. }\end{array}$ & $\begin{array}{l}\text { - Pembuatan SOP distribusi } \\
\text { dokumen dan penanganan } \\
\text { dokumen yang hilang. } \\
\text { - Penyesuaian persebaran } \\
\text { dokumen dengan daftar isi di lini } \\
\text { produksi. }\end{array}$ & $\begin{array}{l}\text { - Mekanisme distribusi } \\
\text { dokumen menjadi jelas. }\end{array}$ \\
\hline $\begin{array}{l}\text { Klausul } 2.4 \\
\text { Attaining Food } \\
\text { Safety and } \\
\text { Quality }\end{array}$ & $\begin{array}{l}\text { Tabel HACCP di area packing lini } \\
\text { produksi belum diperbarui pada } \\
\text { beberapa bagian. } \\
\text { - Matriks penentuan signifikansi } \\
\text { bahaya perlu disesuaikan dengan } \\
\text { aturan CODEX. }\end{array}$ & $\begin{array}{l}\text { - Pembuatan dokumen HACCP } \\
\text { pada lini produksi terkait. } \\
\text { Pembuatan usulan matriks } \\
\text { signifikansi bahaya yang } \\
\text { disesuaikan dengan aturan } \\
\text { CODEX. }\end{array}$ & $\begin{array}{l}\text { - Dokumen HACCP sesuai } \\
\text { dengan keadaan aktual. } \\
\text { - Signifikansi bahaya dalam } \\
\text { sistem HACCP menjadi } \\
\text { seragam. }\end{array}$ \\
\hline $\begin{array}{l}\text { Klausul } 2.9 \\
\text { Training }\end{array}$ & $\begin{array}{l}\text { Evaluasi pemahaman karyawan } \\
\text { sebelum dan sesudah training } \\
\text { belum dilakukan pada setiap } \\
\text { training yang diberikan. }\end{array}$ & $\begin{array}{l}\text { - Pemberian tes singkat untuk } \\
\text { menguji pemahaman karyawan } \\
\text { terkait training yang telah } \\
\text { diberikan. } \\
\text { - Disarankan untuk memberikan } \\
\text { pre-test dan post-test pada } \\
\text { karyawan sebagai tolak ukur } \\
\text { evaluasi. }\end{array}$ & $\begin{array}{l}\text { - Dapat mengetahui tingkat } \\
\text { pemahaman karyawan } \\
\text { terkait training yang } \\
\text { diberikan. } \\
\text { - Proses evaluasi menjadi } \\
\text { lebih mudah. }\end{array}$ \\
\hline
\end{tabular}


Angka tersebut menunjukkan bahwa PT XYZ telah menerapkan persyaratan klausul modul 2 SQF 7.2 dengan sangat baik dan layak mendapatkan sertifikasi. Klausul 2.2 tentang document control and record mendapat nilai 93\% karena belum memiliki SOP baku terkait distribusi dokumen di lini produksi dan masih terdapat duplikasi penyimpanan dokumen elektronik. Pemenuhan klausul 2.4 tentang attaining food safety and food quality mendapat nilai $99 \%$ karena tabel HACCP pada produksi packing 6 belum diperbarui di beberapa bagian. Perusahaan telah memenuhi sebanyak $94 \%$ pada kalusul 2.9 tentang training karena belum semua pelatihan menggunakan metode untuk mengevaluasi pemahaman karyawan terkait pelatihan yang diberikan. Berdasarkan hasil kesenjangan yang diperoleh, usulan tindakan perbaikan diberikan sebagai upaya perbaikan perusahaan dalam memenuhi persyaratan sistem SQF. Pembuatan SOP distribusi dokumen, pembuatan matriks penentuan signifikansi bahaya yang mengacu aturan CODEX; pelaksanaan pre-test dan post-test singkat sebagai tolak ukur tindakan evaluasi hasil pelatihan, dan penggunaan sistem audit online terintegrasi SQF dengan ISO 9001:2015 menggunakan aplikasi iAuditor dapat dijadikan upaya dalam peningkatan efektivitas penerapan sistem SQF di perusahaan.

\section{DAFTAR PUSTAKA}

Bakhtiar A, Bambang P. 2009. Analisis implementasi sistem manajemen kualitas ISO 9001:2000 dengan menggunakan GAP analysis tools (studi kasus di PT PLN (Persero) PIKITRING JBN bidang perencanaan). JATI Undip 3(4): 185-193.

[DAFWA] Department of Agriculture and Food Western Australia. 2000. Taking the SQF 2000 quality code to the world stage. J Department Agr 41(1): 65-67.

[GFSI] Global Food Safety Initiative. 2013. Global Food Safety Initiative. Maryland (US): GSFI. http://www.mygfsi.com/. [9 Februari 2017].

[ISO] International Organization for Standarditation. 2000. ISO 9001 Fifth Edition: Quality Management Systems. Geneva (CH): ISO.
[Kemenperin] Kementrian Perindustrian Republik Indonesia. 2015. Peraturan Menteri Perindustrian Republik Indonesia Nomor 96/M-IND/PER/11/2015 tentang Perubahan atas Peraturan Menteri Perindustrian Nomor 60/MD-IND/PER/7/2015 tentang Pemberlakuan Standar Nasional Indonesia Kukis secara Wajib. Jakarta (ID): Kemenperin RI.

Kobylanski A, Bozena P, Anna S. 2011. The role of customer satisfaction in the quality management systems: a crosscultural study. Int J Management Market Res 4(3): 57-74.

Mensah L, Denyse J. 2011. Implementation of food safety management systems in the UK. Food Control 22(8): 1216-1225. DOI: 10.1016/j.foodcont. 2011.01.021.

Muhandri T, Darwin K. 2012. Sistem Jaminan Mutu Industri Pangan. IPB Press, Bogor (ID).

Netterville R, Adendorff K. 2002. Quality systems in the fresh fruit export industry. J Industrial Eng 13(2): 114. DOI: $10.7166 / 13-2-305$.

Ropkins K, Beck A. 2000. Evaluation of worldwide approaches to the use of HACCP to control food safety. Trends Food Sci Technol 11(1): 10-21. DOI: 10.1016/S0924-2244(00)00036-4.

Seok JH, Michael RR, Sayed S. 2016. The impact of SQF certification on US agri-food exports. Int $\mathrm{J}$ Food Agr Economics 4(3): 1-16.

[SQFI] Safe Quality Food Institute. 2013. SQF Code A HACCP-Based Supplier Assurance Code for the Food Industry Edition 7.1 July 2013. Arlington (US): SQFI.

[SQFI] Safe Quality Food Institute. 2014a. SQF Code: A HACCP-Based Supplier Assurance Code for the Food Industry Edition 7.2 July 2014. Arlington (US): SQFI.

[SQFI] Safe Quality Food Institute. 2014b. General Guidance for Developing, Documenting, Implementing, Maintaining, and Auditing an SQF System-Module 2: System Elements SQF Code, Edition 7.2. Arlington (US): SQFI.

JMP-05-18-18-Naskah diterima untuk ditelaah pada 27 Mei 2018. Revis makalah disetujui untuk dipublikasi pada 09 Maret 2019. Versi Online: http://journal.ipb.ac.id/index.php/jmpi 